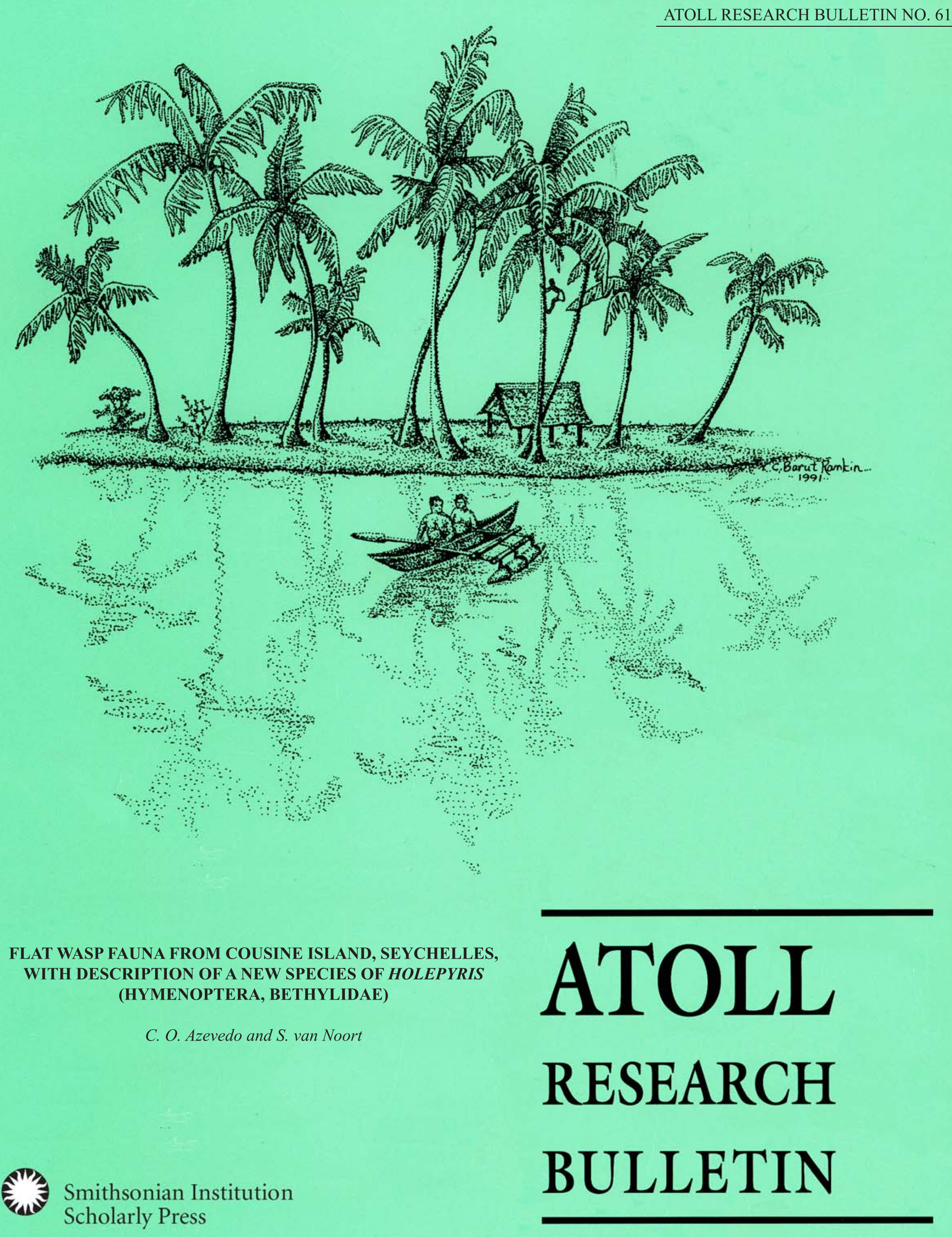




\title{
FLAT WASP FAUNA FROM COUSINE ISLAND, SEYCHELLES, WITH DESCRIPTION OF A NEW SPECIES OF HOLEPYRIS (HYMENOPTERA, BETHYLIDAE)
}

\author{
C. O. Azevedo and S. van Noort
}

Atoll Research Bulletin No. 615 14 March 2018

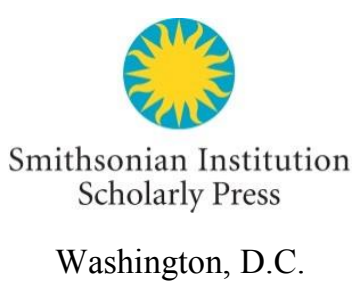


All statements made in papers published in the Atoll Research Bulletin are the sole responsibility of the authors and do not necessarily represent the views of the Smithsonian Institution or of the editors of the bulletin. Articles submitted for publication in the Atoll Research Bulletin should be original papers and must be made available by authors for open access publication. Manuscripts should be consistent with the "Author Formatting Guidelines for Publication in the Atoll Research Bulletin." All submissions to the bulletin are peer reviewed and, after revision, are evaluated prior to acceptance and publication through the publisher's open access portal, Open SI (http://opensi.si.edu).

Published by SMITHSONIAN INSTITUTION SCHOLARLY PRESS

P.O. Box 37012, MRC 957

Washington, D.C. 20013-7012

https://scholarlypress.si.edu/

The rights to all text and images in this publication are owned either by the contributing authors or by third parties. Fair use of materials is permitted for personal, educational, or noncommercial purposes. Users must cite author and source of content, must not alter or modify the content, and must comply with all other terms or restrictions that may be applicable. Users are responsible for securing permission from a rights holder for any other use.

ISSN: 0077-5630 (online) 


\title{
FLAT WASP FAUNA FROM COUSINE ISLAND, SEYCHELLES, WITH DESCRIPTION OF A NEW SPECIES OF HOLEPYRIS (HYMENOPTERA, BETHYLIDAE)
}

\author{
C. O. AZEVEDO ${ }^{1,2}$ and S. VAN NOORT $T^{2,3}$
}

\begin{abstract}
The species richness of the flat wasp fauna from Cousine Island, Seychelles, is reported for the first time. Three species are represented on this island in the Seychelles archipelago. The male of the previously described Seychelles species, Goniozus kiefferi Gordh is redescribed and its genitalia described and illustrated for the first time; the Oriental species Megasprosternum cleonarovorum Gupta and Azevedo, previously known from India, is recorded for the first time from the Seychelles and the Afrotropical region; and Holepyris gaigherae sp. nov. is described and illustrated. The Seychelles flat wasp fauna is now represented by nine species in total recorded from Cousine, Mahé and Silhouette islands.
\end{abstract}

\section{KEY WORDS}

Bethylidae, Chrysidoidea, endemism, Goniozus, Holepyris, Megasprosternum, Pheidole.

\section{INTRODUCTION}

The flat wasp (Hymenoptera, Bethylidae) fauna of Seychelles is very poorly surveyed and studied. Currently the recorded fauna comprises only seven species (Table 1), all of them reported by Kieffer (1912).

Table 1. Flat wasp fauna of Seychelles $\left(*=\right.$ Kieffer $1912 ;{ }^{\dagger}=$ present study).

\begin{tabular}{|c|c|}
\hline Species & Island \\
\hline Apenesia pallidimanus (Kieffer, 1912) & Mahé* \\
\hline Apenesia remota (Kieffer, 1912) & Mahé* \\
\hline Dissomphalus excisicrus Kieffer, 1912 & Mahé* \\
\hline Dissomphalus saxatilis Kieffer, 1912 & Mahé* \\
\hline Goniozus kiefferi Gordh, 1986 & Mahé*, Silhouette*, Cousine $^{\dagger}$ \\
\hline Holepyris gaigherae Azevedo \& van Noort, sp. nov. & Cousine $^{\dagger}$ \\
\hline Megaprosternum cleonarovorum Gupta \& Azevedo, 2017 & Cousine $^{\dagger}$ \\
\hline Parascleroderma seychellensis Kieffer, 1912 & Silhouette* \\
\hline Pseudisobrachium cruciferum (Kieffer, 1912) & Mahé*, Silhouette*, Praslin* \\
\hline
\end{tabular}

Cousine Island is a 27 ha granitic island in the Seychelles archipelago situated at $4^{\circ} 20^{\prime} 41^{\prime \prime} \mathrm{S}$ and

\footnotetext{
${ }^{1}$ Universidade Federal do Espírito Santo, Departamento de Ciências Biológicas, Av. Fernando Ferrari, 510, Goiabeiras 29.075-910 Vitória ES, Brazil. E-mail: bethylidae@gmail.com

${ }^{2}$ Research \& Exhibitions Department, Iziko South African Museum, PO Box 61, Cape Town, 8000, South Africa.

E-mail: svannoort@iziko.org.za

${ }^{3}$ Department of Biological Sciences, University of Cape Town, Private Bag, Rondebosch, 7701, South Africa.
} 
55 $38^{\prime} 44^{\prime \prime}$ E (Gaigher et al. 2011). Vegetation on the island is mostly composed of indigenous forest dominated by Pisonia grandis R.Br., Ficus reflexa Thunb., Ficus lutea Vahl, Euphorbia pyrifolia Lam., and Pandanus balfourii Martelli (Figures 1-2) (Samways et al. 2010).

The mean monthly temperature for the period during which the survey was carried out by René Gaigher (May 2010 to May 2011) was $27.5 \pm 0.2^{\circ} \mathrm{C}$, with a minimum of $22.2^{\circ} \mathrm{C}$ and a maximum of $33.2^{\circ} \mathrm{C}$, and the mean monthly rainfall was $92.3 \pm 28.3 \mathrm{~mm}$ and mean humidity was $87.3 \pm 1.1$ percent relative humidity (Gaigher and Samways 2013).
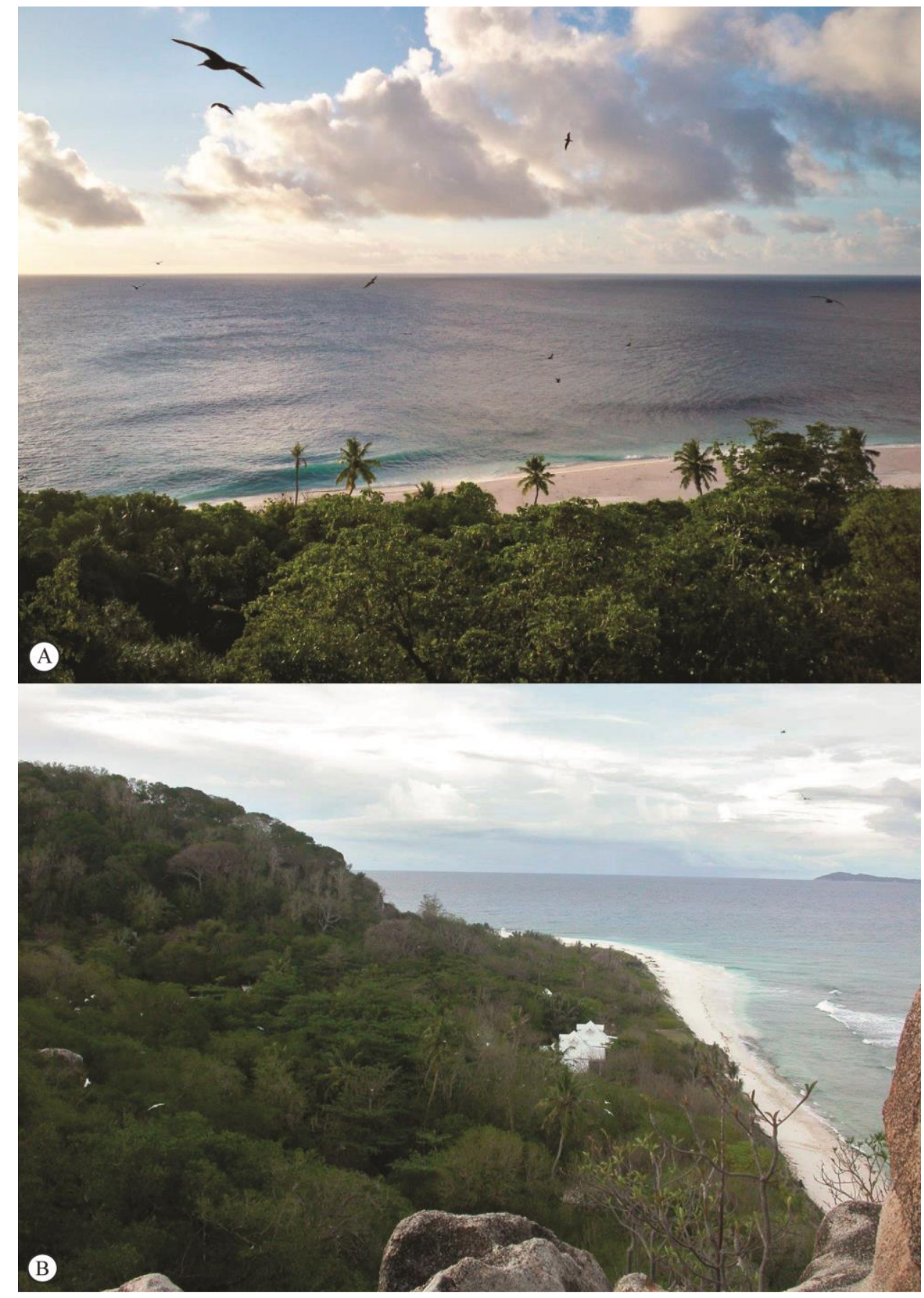

Figure 1. Cousine Island, Pisonia grandis forest (A) View from North hill (B) View from South ridge. Photographs by Rene Gaigher (used with permission). 


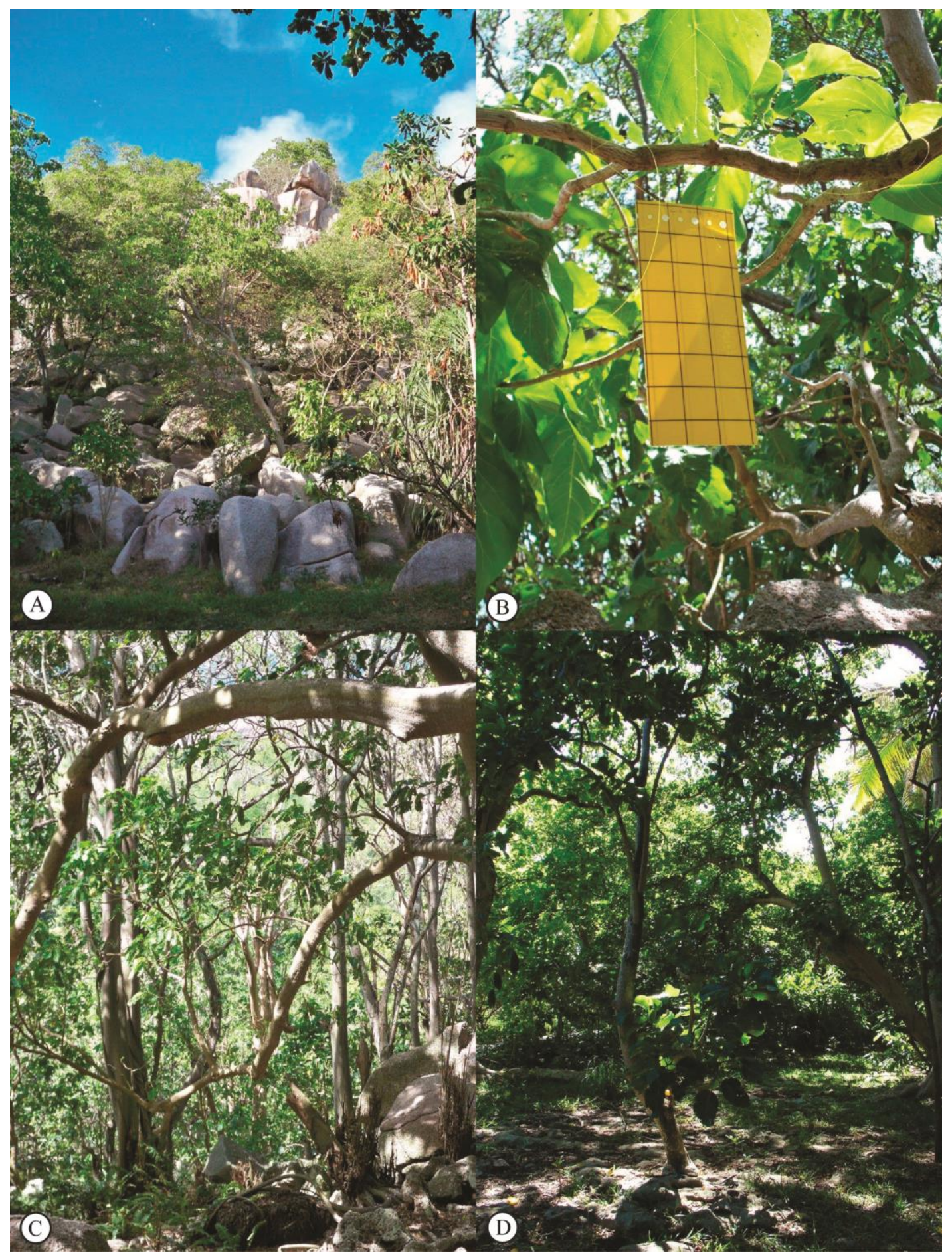

Figure 2. Cousine Island, Pisonia grandis forest (A) Coastal plateau forest (B) Yellow sticky trap suspended in lower canopy (C) Interior view of forest on North hill (D) Interior view of coastal plateau forest. Photographs by Rene Gaigher (used with permission).

Parasitoid wasps were collected under the scope of a project for which the main goal was to assess the impact of interference by a highly invasive ant, Pheidole megacephala Fabricius, on the natural enemy assemblage regulation of a tree-destroying hemipteran scale insect, Pulvinaria urbicola (Gaigher et al. 
2013). The collection site was a continuous area of 8 ha on the north hill and northern plain (Figure 2), where the ants occurred in very high densities (Gaigher et al. 2011). The wasps were either collected with eight yellow sticky traps $(9 \mathrm{~cm} \times 20 \mathrm{~cm})$ hung in the lower canopy (Figure $2 \mathrm{~B})$ or directly aspirated from vegetation in the lower canopy (Gaigher and Samways 2013).

Gaigher et al. (2013) recorded three undetermined genera of flat wasps during their survey of Cousine Island, each genus represented by a single species. The main goal of this paper is to provide the identification of these bethylid species and to describe the new species recorded during this survey.

\section{MATERIAL AND METHODS}

The bethylid material collected under the project aforementioned is deposited in the Iziko South African Museum, Cape Town (SAMC, curator S. van Noort).

The style of description and acronyms for measurements follow Evans (1964). The terms for general morphology follow Hymenoptera Anatomy Ontology (Yoder et al. 2010), except for the terms related to metapectal-propodeal complex, which follow Kawada et al. (2015). The terms of integument follow Harris (1979).

The abbreviations for biometric measurement used in the text are as follow: DAO, diameter of anterior ocellus; HE, height (length) of eye in lateral view; LH, length of head, from apical margin of clypeus to vertex crest in dorsal view; POL, distance between posterior ocelli in dorsal view; VOL, vertex-ocular line, distance between eye tops to vertex crest in full dorsal view; WF, width of frons, shortest distance between eyes in dorsal view; WH, maximum width of head in dorsal view; and WOT, width of the ocellar triangle.

The specimens were examined under a Leica M165C Stereo Microscope. Prior to dissection of the male genitalia the body in toto was submersed in ammoniac solution to soften the tissues, following which the posterior third of the metasoma was separated from the rest of the body and submersed in $10 \%$ $\mathrm{KOH}$ solution for a period of 24 hours for clearing of the internal tissues. The hypopygium and genitalia were then separated and stored in a microvial with glycerin.

Images were acquired with a Leica LAS 4.9 imaging system, comprising a Leica ${ }^{\circledR}$ Z16 microscope with a Leica DFC450 Camera and $0.63 \times$ video objective attached. The imaging process, using an automated Z-stepper, was managed using the Leica Application Suite V 4.9 software installed on a desktop computer. All images presented in this paper, as well as supplementary images, are available at www.waspweb.org.

\section{RESULTS}

The material classified as Genus A sp. 1, Genus B sp. 1 and Genus C sp.1 by Gaigher et al. (2013, page 2118) are identified here as Goniozus kiefferi Gordh, 1986, Holepyris gaigherae sp. nov., and Megasprosternum cleonarovorum Gupta and Azevedo, 2017, respectively.

\section{Goniozus kiefferi Gordh, 1986}

Parasierola rostrata Kieffer, 1912:47 [male and female descriptions].-Kieffer, 1914:534 [key], 536 [male and female descriptions].

Goniozus kiefferi Gordh, 1986:264 [replacement name].—Gordh and Móczár, 1990:21 [catalogue].

Description of male (Figures 3-4)

Body length $2.31 \mathrm{~mm}$ (Figure 3A, B). Length of forewing $1.5 \mathrm{~mm}$. Color. Head and mesosoma blackish; mandible, palpi, antenna and pale yellowish legs, dorsal face of legs darker; forewing 

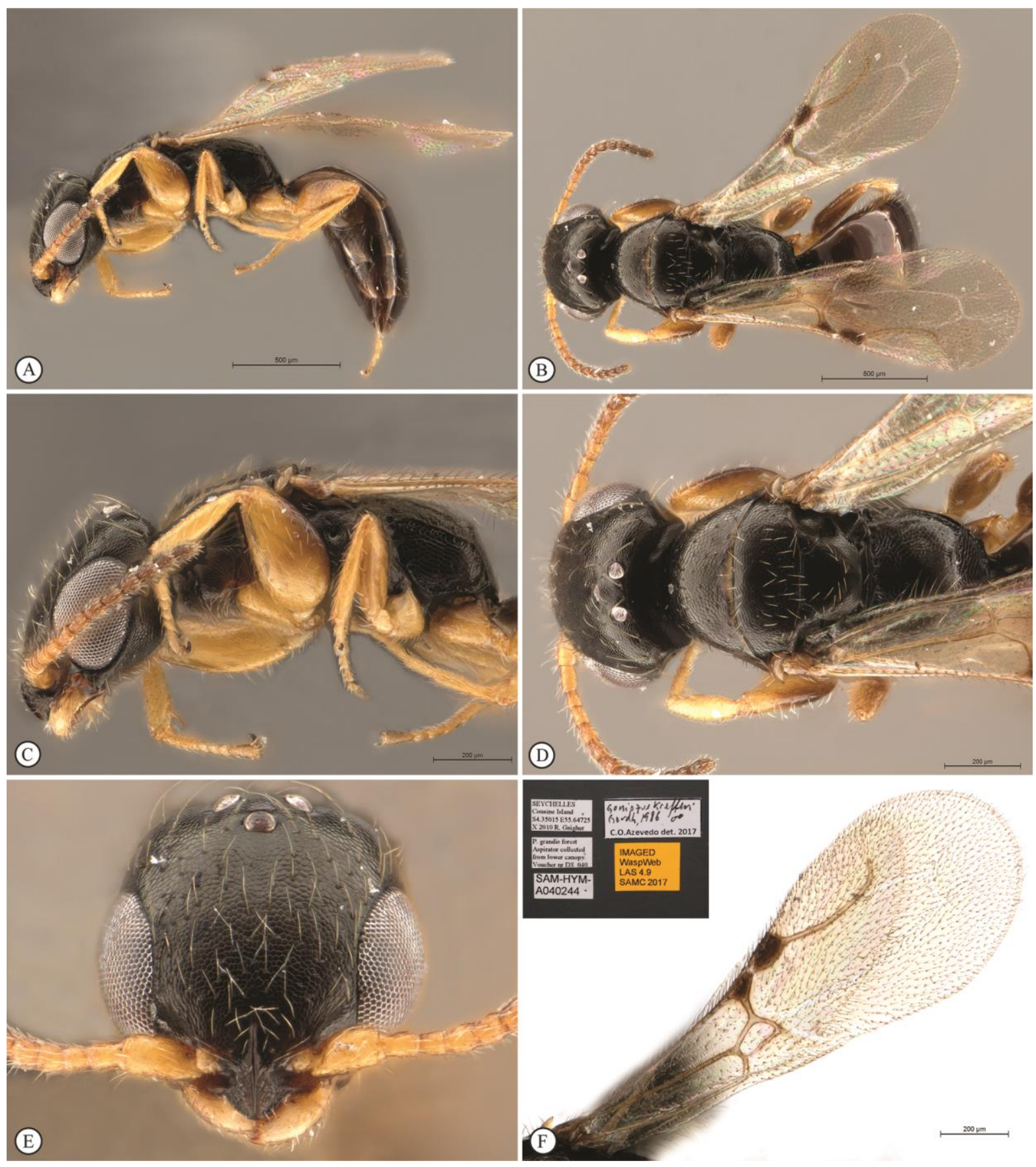

Figure 3. Male of Goniozus kiefferi Gordh, 1986. (A) Habitus, lateral view (B) Habitus, dorsal view (C) Head and mesosoma, lateral view (D) Head and mesosoma, dorsal view (E) Head, anterior view (F) Wings (inset: data labels).

subhyaline, veins brown, stigma and prostigma darker; metasoma dark brown.

Head (Figure 3E). Mandible with four small distal teeth, subequal in size, dorsalmost one wider. Clypeus with rounded median lobe, median carina elevated, narrow, sharp-topped, extending posteriorly into frons, slightly outcurved in profile. Antenna short, $0.76 \mathrm{~mm}$ long, surpassing tegula; not distinctly moniliform, flagellomeres progressively wider distally, length of first four antennomeres in ratio of about 15:8:5:6; scape only slightly curved, almost evenly wide along its extension, short and thick, maximum width only $0.6 \times$ maximum length; pedicel much longer than wide; flagellar pubescence median-sized, 
appressed, with few suberect and erect setae outstanding over regular pubescence, flagellomeres with conspicuous elongate sensillae forming distal ring. Eye very large, with sparse and short setae, subtriangular in lateral view. Frons coriaceous, punctures small, shallow, inconspicuous, somewhat irregularly distant one another; frontal line carinate. $\mathrm{LH} 1.07 \times \mathrm{WH}$. WF $0.62 \times \mathrm{WH}$. WF $1.15 \times \mathrm{HE}$. OOL $1.07 \times$ WOT. VOL $0.5 \times$ HE. Ocellar triangle touching vertex crest. Anterior ocellus distant from imaginary line between eye tops about $0.93 \times$ DAO. Frontal angle of ocellar triangle less than right; ocellar triangle broad, POL $1.37 \times$ DAO. Vertex broad and straight. Lateral profile of head very convex in dorsal view. Occipital carina not visible in full dorsal view. Malar space very reduced, eye almost touching mandible.

Mesosoma (Figure 3C, D). Thorax coriaceous as frons. Pronotal disc subtrapezoidal, longer than wide, disc and slope of pronotal collar not outlined. Anteromesoscutum and mesoscutellum about equally long, notauli absent, parapsidal signum complete, straight, very narrow, inclined. Mesoscutellar pits narrow, inclined, elliptical with sharp ends. Metapectal-propodeal disc coriaceous-areolate; median length $0.58 \times$ median width, metapostnotal median, metapostnotal lateral, metapostnotal-propodeal and paraspiracular carinae absent; metapleural carina complete, posterior carina absent medially. Declivity of propodeum weakly areolate, surface flat, inclined, median carina absent. Lateral portion of propodeum weakly areolate. Mesopleuron with mesopleural pit small. Forewing with closed $1 \mathrm{M}$ cell, prostigma large and triangular, stigma large, $1.5 \times$ as long as wide, end of r-rs\&Rs vein slightly angled anterad (Figure $3 F)$. Hind wing with four distal hamuli at stigma level. Legs not spinose. Claws with two large sharpened teeth.

Metasoma. Polished to weakly coriaceous, cross-section elliptical. Hypopygium subquadrate, median stalk $0.73 \times$ plate length, lateral stalk absent, posterior margin straight (Figure 4D). Genitalia (Figure 4AC): paramere somewhat wide, dorsal and ventral margins almost straight, apical margin subtruncate, outer surface wholly hairy, inner surface strongly concave; cuspis progressively wider apicad, apical margin truncate with small median emargination, its apex slightly higher than aedeagus apex; digitus laminar, wide, apex rounded, proximal area denticulate on dorsal surface; aedeagus bottle-shaped, with pair of apical lobes somewhat rounded.

\section{Material examined}

Three males: Seychelles, Cousine Island, S4.35015 E55.64725, X.2010, R. Gaigher, P. grandis forest, Aspirator collected from lower canopy, voucher nr DS 040 (SAM-HYM-A032044, SAM-HYMA032045, SAM-HYM-A032048).

\section{Remarks}

This species was originally reported for Silhouette and Mahé (Kieffer 1912) and here it is recorded for the first time from Cousine Island. It was described as Parasierola rostrata by Kieffer (1912), but Gordh (1986) replaced the name in order to eliminate the secondary homonym with Goniozus rostratus Kieffer, 1905. This was the result of the synonymization of Parasierola Cameron under Goniozus Förster by Evans (1978). The species is known from both sexes, but the male genitalia had not been previously described.

Goniozus kiefferi is easily recognized by its coloration. The mandibles, palpi, antennae and legs are mostly pale yellowish contrasting with the dark brown body. Some other characters that are useful to recognize the species are: the ocellar triangle touches the vertex crest; the frontal angle of the ocellar triangle is slightly less than right-angled; the vertex is broadly straight; the head is just slightly longer than wide; the frons is broad; the head appears to be rounded, because the eyes are large and the sides of the head are strongly convex; the antennae are not notably moniliform as is the normal pattern for the genus, rather the flagellomeres progressively widen towards the distal end, and conspicuous elongate sensillae form a distal ring on the antennae; the 1M cell (areolet in Evans' sense) is closed in the forewing (Figure 3F).

There are no variations in the examined series of specimens that are worthy of mention. 

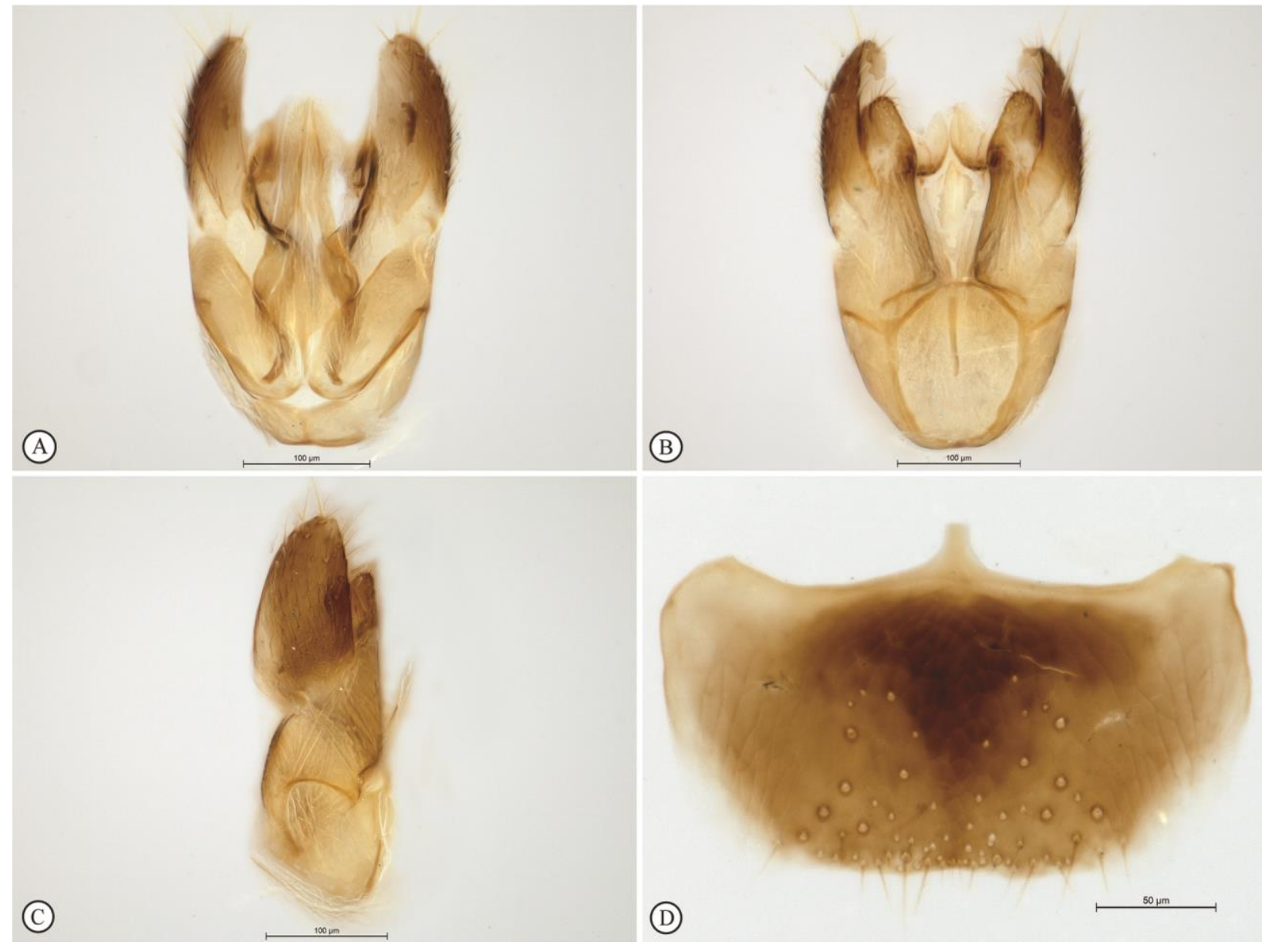

Figure 4. Goniozus kiefferi Male (A) Genitalia, dorsal view (B) Genitalia, ventral view (C) Genitalia, lateral view (D) Hypopygium, ventral view.

\section{Distribution}

This species is endemic to the Seychelles archipelago (Cousine, Mahé and Silhouette islands).

\section{Holepyris gaigherae Azevedo and van Noort, sp. nov.}

\section{Description of female (Figure 5)}

Body length $2.55 \mathrm{~mm}$ (Figure 5A, B). Length of forewing $0.16 \mathrm{~mm}$. Color. Head and mesosoma blackish; antenna brown to dark brown; mandible dark brown; clypeus and palpi light brown; legs dark brown with tarsi lighter; forewing hyaline, veins whitish; metasoma dark brown.

Head (Figure 5C, D). Mandible with two small distal teeth, subequal in size. Clypeus with three rounded lobes well delimited by sharp and deep excavation, median lobe slightly wider and longer than lateral ones; median carina elevated, narrow, sharp-topped, almost straight in profile. Antenna $1.0 \mathrm{~mm}$ long, surpassing mesoscutellum; first four antennomeres in ratio of about 20:10:6:9; scape only slightly curved, almost evenly wide along its extension; pedicel much longer than wide; flagellar pubescence very short, dense and appressed, with few suberect and erect setae outstanding over regular pubescence. Eye very large and stout, with sparse and short setae, suboval in lateral view. Frons coriaceous, punctures small, shallow, inconspicuous, somewhat irregularly distant one another; frontal line carinate. LH $1.44 \times$ WH. WF $0.52 \times$ WH. WF $0.64 \times$ HE. OOL $0.94 \times$ WOT. VOL $0.34 \times$ HE. Distance of posterior ocellus to vertex crest $0.33 \times \mathrm{DAO}$. Anterior ocellus distant from imaginary line between posterior eye margin $1.67 \times$ DAO. Frontal angle of ocellar triangle right-angled; ocellar triangle broad, POL $4.0 \times$ DAO. 

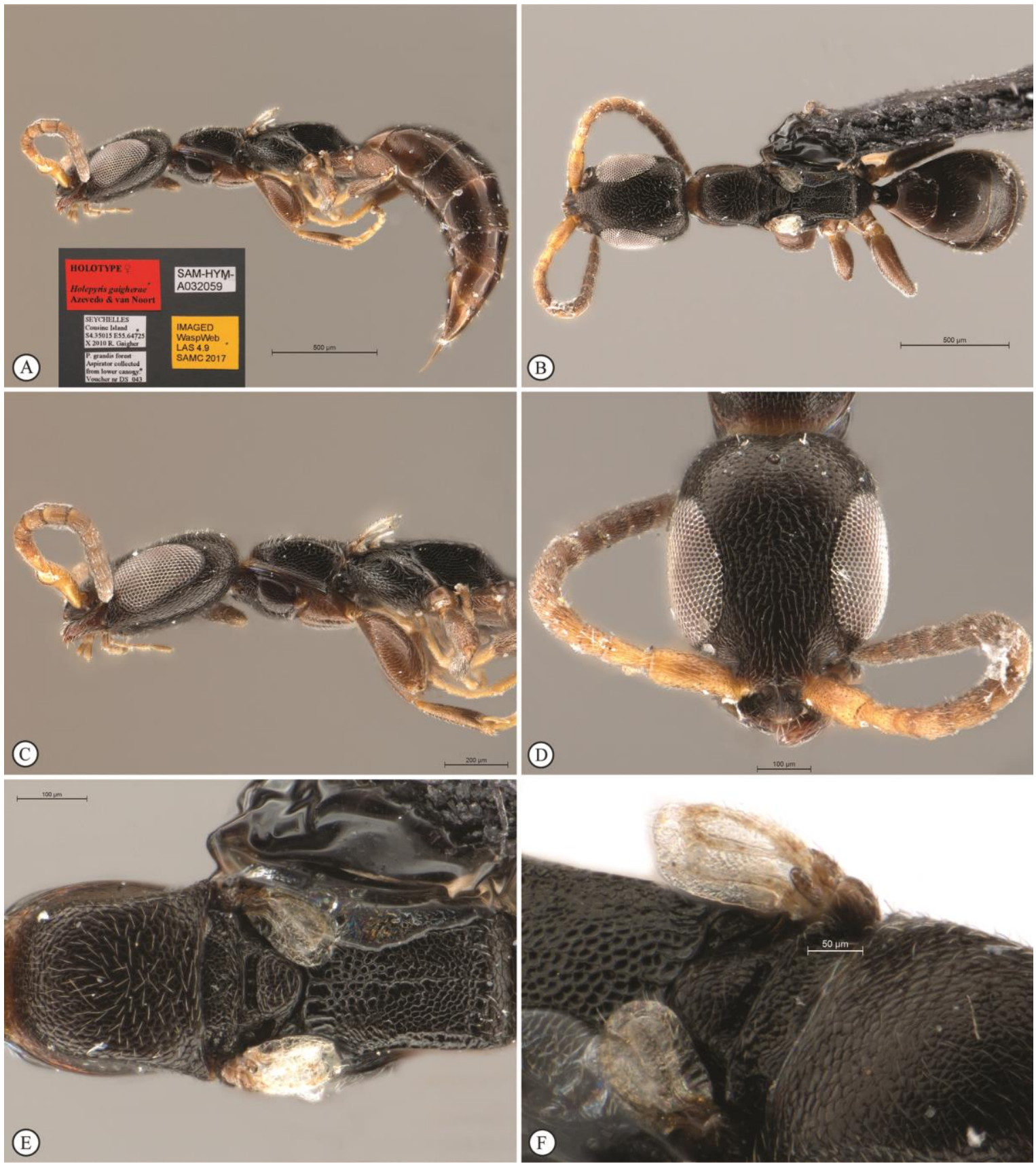

Figure 5. Female of Holepyris gaigherae sp. nov. (A) Habitus, lateral view (inset: data labels) (B) Habitus, dorsal view (C) Head and mesosoma, lateral view (D) Head, anterior view (E) Mesosoma, dorsal view (F) Wings.

Vertex almost straight, slightly incurved medially. Sides of head posterior to eye convergent posterad. Occipital carina not visible in dorsal view.

Mesosoma (Figure 5C, E). Pronotal disc slightly more coriaceous than frons, subtrapezoidal, longer than wide, anterior face outcurved; disc and slope of pronotal collar not well outlined. Anteromesoscutum and mesoscutellum strongly coriaceous, former shorter than latter, notauli and parapsidal signum not distinguishable. Mesoscutellar sulcus conspicuous, straight, deep, wide, weakly trabeculate inside, lateral end not dilated at all. Metapectal-propodeal disc wholly areolate; median length $1.38 \times$ median width, metapostnotal median carina complete, but very weak and irregular; metapostnotal lateral and 
metapostnotal-propodeal carinae very reduced, almost like stub; paraspiracular carina weak, present only at posterior half of disc; metapleural carina complete, but weak, posterior carina absent. Declivity of propodeum coriaceous, surface flat, inclined, median carina absent. Lateral of metapectal-propodeal complex coriaceous. Mesopleuron with mesopleural pit small, and upper callus somewhat produced. Brachypterous, forewing with three closed cells $(\mathrm{C}, \mathrm{R}$ and $1 \mathrm{Cu})$, stigma and r-rs\& Rs vein absent (Figure 5F). Legs not spinose.

Metasoma. Coriaceous, cross-section elliptical.

Material examined

Holotype, female, Seychelles, Cousine Island, S4.35015 E55.64725, X.2010, R. Gaigher, P. grandis forest, Aspirator collected from lower canopy, voucher nr DS 043 (SAM-HYM-A032059). Paratypes: 3 females with same data as holotype (SAM-HYM-A032060, SAM-HYM-A032061, SAM-HYMA040246).

\section{Variation}

Body length 2.2 to $2.9 \mathrm{~mm}$; length of forewing 0.15 to $0.24 \mathrm{~mm}$; antenna, legs and metasoma darker; LH 1.28 to $1.32 \times \mathrm{WH}$; WF 0.46 to $0.5 \times \mathrm{WH}$; WF 1.32 to $1.5 \times \mathrm{HE}$; OOL 0.83 to $1.07 \times \mathrm{WOT}$. VOL 0.38 to $0.45 \times \mathrm{HE}$; distance of posterior ocellus to vertex crest 0.4 to $0.6 \times \mathrm{DAO}$; anterior ocellus distant from imaginary line between posterior eye margin 1.8 to $2.2 \times$ DAO; POL 4.0 to $4.7 \times \mathrm{DAO}$; metapectalpropodeal disc with median length 1.29 to $1.37 \times$ median width; metapostnotal median carina incomplete posteriorly or wholly indistinguishable from the areolate surface.

\section{Remarks}

The continental Afrotropical fauna of Holepyris includes 13 species. Only Holepyris sylvaticus Turner, 1928 is brachypterous, but there are several conspicuous differences with Holepyris gaigherae sp. nov. The former has the LH $1.2 \times \mathrm{WH}$, the mandibles have one tooth, the metapostnotal median carina is well marked, the forewings reach the transverse posterior carina of the metapectal-propodeal complex and the r-rs\&Rs vein is present, whereas Holepyris gaigherae sp. nov. has the LH $1.44 \times \mathrm{WH}$, the mandibles have two teeth, the metapostnotal median carina is poorly delimited, the forewings just surpass the transverse anterior carina of the metapectal-propodeal complex and the r-rs\&Rs vein is absent.

\section{Etymology}

This species is named after the collector René Gaigher who carried out the survey of arthropods associated with Pisonia grandis forest on Cousine Island in the Seychelles archipelago. The specific epithet is a noun in the genitive case.

\section{Distribution}

This species is probably endemic to the Seychelles archipelago (currently only known from Cousine Island).

\section{Megasprosternum cleonarovorum Gupta and Azevedo, 2017}

Megasprosternum cleonarovorum Gupta and Azevedo, 2017:79-84 [male and female descriptions]; 8488 [biology]; 89 [key].

This species was described from India in the state of Karnataka by Gupta et al. (2017), and here we record the species for the first time from Seychelles. The five females studied here were collected in the upper canopy forest of Pisonia grandis (Nyctaginaceae) attacking Coleoptera (Gaigher et al. 2013). 

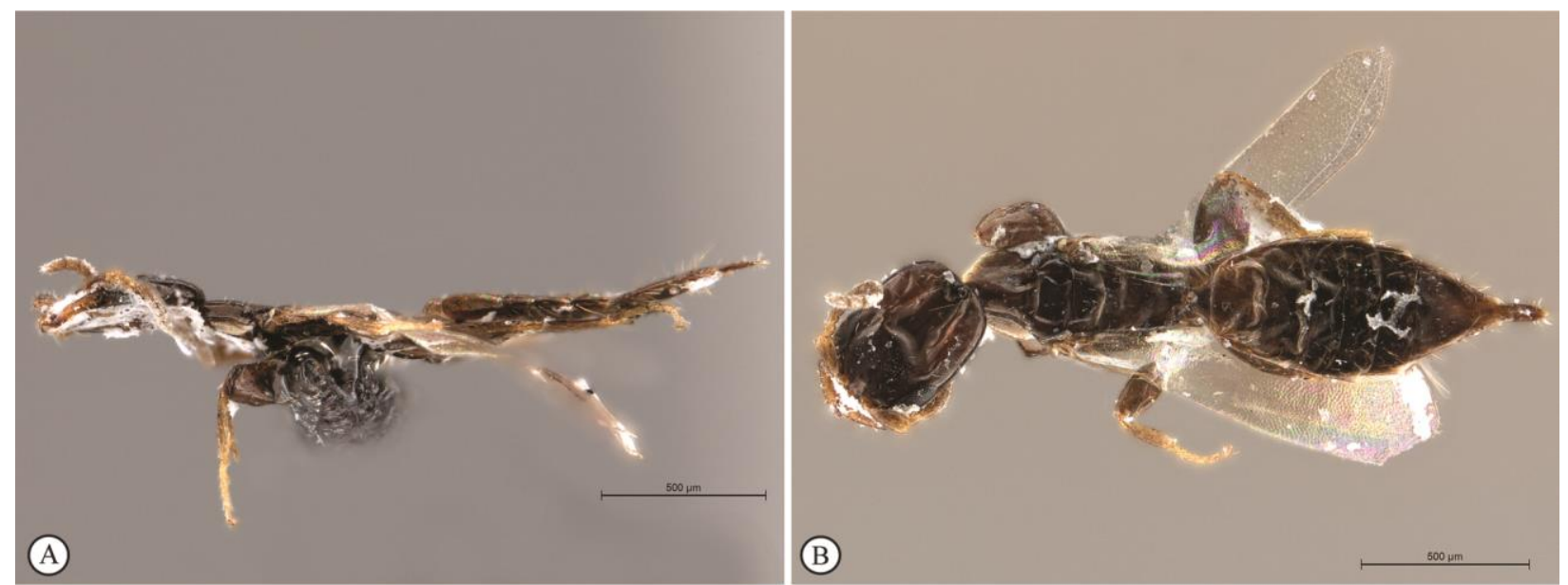

\section{(A)}

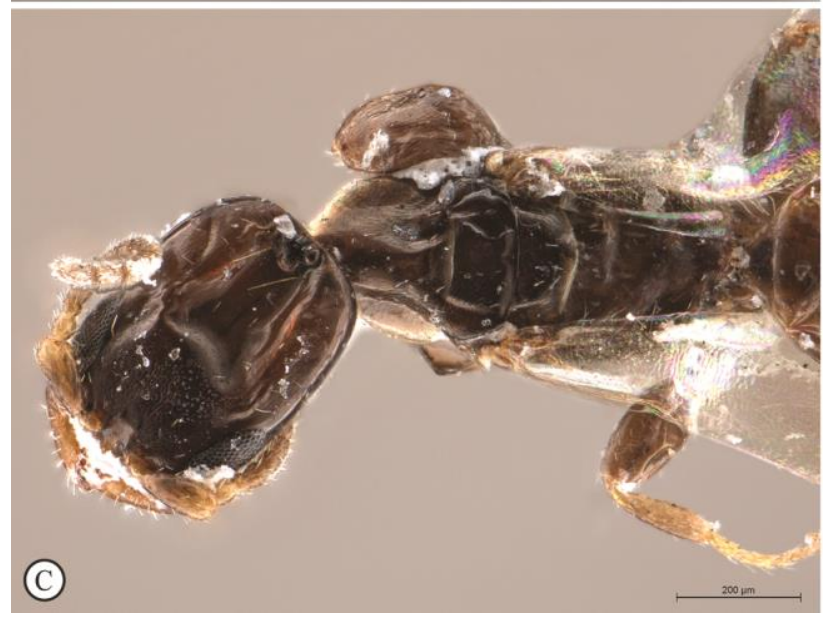

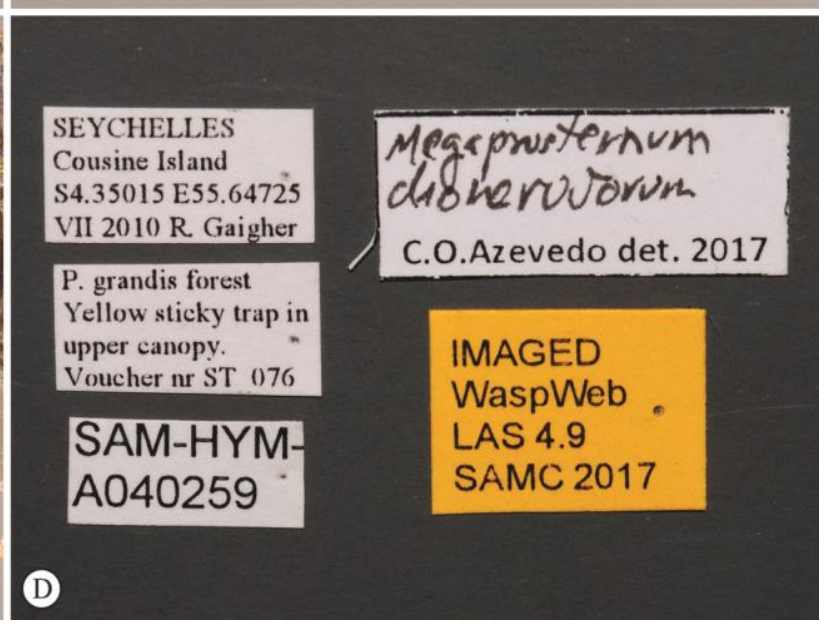

Figure 6. Female of Megaprosternum cleonarovorum Gupta and Azevedo, 2017. (A) Habitus, lateral view (B) Habitus, dorsal view (C) Head and mesosoma, dorsal view (D) Data labels.

Two characters are important to recognize this species as highlighted in the key provided by Gupta et al. (2017), which separate the only two species of this genus known from females. Megasprosternum cleonarovorum has fully developed wings and the mesoscutum divided into mesoscutum and mesoscutellum, in contrast to aptery and an undivided mesoscutum in Megasprosternum longiceps Azevedo.

This species has an accentuated polymorphism in the shape of the head in both males and females (Gupta et al. 2017). In the series studied here all five females are very similar to one another and all have the head rectangular exactly as in the allotype (Figure 6). Although there is a large distance between the Seychelles and the type locality of Megasprosternum cleonarovorum in Bangalore, India, there are no morphological variations between specimens from the two localities that are worthy of mention.

\section{Material examined}

Five females: Seychelles, Cousine Island, S4.35015 E55.64725, VII.2010, R. Gaigher, P. grandis forest, Yellow sticky trap in upper canopy (Figure 2B), voucher nr ST 076 (SAM-HYM-A032089, SAMHYM-A040257, SAM-HYM-A040258, SAM-HYM-A040259, SAM-HYM-A040260).

All the specimens studied here were collected using yellow sticky traps, because of this method the specimens have collapsed and some parts are covered with glue. Although the specimens are in a relatively poor state of preservation, the diagnostic characters required for species delimitation are clear enough for precise identification. 


\section{Distribution}

This species is known from India (Karnataka) and the Seychelles archipelago (Cousine Island).

\section{DISCUSSION}

The flora and fauna of small oceanic islands often includes many endemic species, which play important biological roles (Omelko 2012). The Seychelles islands are particularly interesting from a biogeographical perspective, because they have ancient affinities to both Africa and Asia, but also include more recent colonization by species from the Indo-Pacific region, as well as very recent introductions from various parts of the world as a result of modern anthropogenic globalization trends (Omelko 2012).

The Seychelles archipelago was separated from India by the Late Cretaceous at about $84 \mathrm{Ma}$ (Plummer \& Belle 1995). Thus the presence of Megasprosternum cleonarovorum in both India and the Seychelles cannot be explained by a vicariance event. It is more likely that the species has been introduced to either the Seychelles or India, from wherever the species' native distribution is centered, which is currently unconfirmed given the lack of baseline distribution data. Alternatively the species may be widespread, but under-sampled or rare in the intervening geographical areas.

Although the Seychelles insect fauna was first surveyed more than a century ago (e.g. Scott 1910), only Kieffer (1912) studied the bethylid fauna from this archipelago (Table 1). He described all seven species (Apenesia pallidimanus, A. remota, Dissomphalus excisicrus, D. saxatilis; Goniozus kiefferi Parascleroderma seychellensis, Pseudisobrachium cruciferum) mostly from Mahé Island. Here we add two more species (Holepyris gaigherae and Megasprosternum cleonarovorum) to the archipelago's bethylid fauna. Given that bethylids are parasitoids of several families of moths (Lepidoptera) and beetles (Coleoptera) (Evans 1978), it is unlikely that the three species recorded in Gaigher et al. (2013) had any impact on the ant-scale mutualism detailed in this study.

The flat wasp species of Seychelles are almost all endemic, the only exception being Megaprosternum cleonarovorum. The genus Megaprosternum Azevedo has only three species with a disjunct distribution, M. cleonarovorum from Bangalore, India (Gupta et al. 2017), M. longiceps Azevedo from Fiji and M. pentagonal Azevedo from Brisbane, Australia (Azevedo 2006). The specimens of $M$. cleonarovorum studied here were collected in Pisonia grandis forest. This plant is native to tropical islands in the Indian and Pacific Oceans plus adjoining coastal areas, ranging from Madagascar to Polynesia (Missouri Botanical Garden 2017). Thus we can hypothesize that there may be a relationship between Pisonia grandis and Megaprosternum, which would help to explain the occurrence of Megaprosternum in the Seychelles. Possibly the host beetle is strongly associated with Pisonia grandis. A similar pattern of distribution was found for the butterfly Diaphana indica (Saunders) (Laurence 2005).

\section{ACKNOWLEDGEMENTS}

This contribution was supported by CNPq (Conselho Nacional de Desenvolvimento Científico e Tecnológico) grant \#305746/2014-6. Simon van Noort was funded by South African NRF (National Research Foundation) grants: GUN 81139; GUN 98115. We thank René Gaigher for collecting the specimens, for making them available for description and for the use of her habitat photographs. We also thank the editor Marguerite Toscano and the revisers who helped to improve the text.

\section{REFERENCES}

Azevedo, C. O. 2006. Two new genera of Sclerodermini (Hymenoptera, Bethylidae, Epyrinae) with large, scolebythid-like prosternums. Zootaxa, 1191:35-47. 
Evans, H. E. 1964. A synopsis of the American Bethylidae (Hymenoptera, Aculeata). Bulletin of the Museum of Comparative Zoology, 132:1-222.

Gaigher, R. and N. J. Samways. 2013. Strategic management of an invasive ant-scale mutualism enables recovery of a threatened tropical tree species. Biotropica, 45:128-134. http://doi.org/10.1111/j.1744-7429.2012.00898.x.

Gaigher, R., N. J. Samways, J. Henwood and K. Jolliffe. 2011. Impact of a mutualism between an invasive ant and honeydew-producing insects on a functionally important tree on a tropical island. Biological Invasions, 13: 1717-1721. https://doi.org/10.1007/s10530-010-9934-1.

Gaigher, R., M. J. Samways and S. van Noort. 2013. Saving a tropical ecosystem from a destructive antscale (Pheidole megacephala, Pulvinaria urbicola) mutualism with support from a diverse natural enemy assemblage. Biological Invasions, 15:2115-2125. https://doi.org/10.1007/s10530-0130437-8.

Gordh, G. 1986. A new species of Goniozus Foerster 1851 from southern Africa parasitizing sugar cane borer, Eldana saccharina Walker, and taxonomic notes on species of the genus in Africa (Hymenoptera: Bethylidae; Lepidoptera: Pyralidae). Journal of the Entomological Society of Southern Africa, 49:257-265.

Gordh, G. and L. Móczár. 1990. A catalog of the world Bethylidae (Hymenoptera: Aculeata). Memoirs of the American Entomological Institute, 46:1-364.

Gupta, A., S. K. Rajeshwari and C. O. Azevedo. 2017. Biology and description of Megaprosternum cleonarovorum sp. nov. (Hymenoptera: Bethylidae) a gregarious larval ectoparasitoid of Cleonaria bicolor Thomson (Coleoptera: Cerambycidae) from India. Zootaxa, 4237:078-090. https://doi.org/10.11646/zootaxa.4237.1.4.

Harris, R. A. 1979. A glossary of surface sculpturing. Occasional Papers in Entomology, 28:1-31.

Kawada, R., G. O. Lanes and C. O. Azevedo. 2015. Evolution of metapostnotum in flat wasps (Hymenoptera, Bethylidae): implications for homology assessments in Chrysidoidea. PLoS ONE, 10(10):e0140051. https://doi.org/10.1371/journal.pone.0140051.

Kieffer, J. J. 1912. No. IV. -Hymenoptera, Proctotrupoidea. Transactions of the Linnean Society of London, Series 2, 15:45-80. https://doi.org/10.1111/j.1096-3642.1912.tb00089.x.

Lawrence, J. M. 2005. The Lepidoptera of Cousine Island, Seychelles. Phelsuma, 13:94-101.

Missouri Botanical Garden. 2017. Pisonia grandis. http://www.missouribotanicalgarden.org/PlantFinder/PlantFinderDetails.aspx?taxonid=291705\&i sprofile $=0 \&$.

Omelko, M. M. 2012. Book review: Gerlach J, Marusik Y (Eds) (2010) Arachnida and Myriapoda of the Seychelles islands. Siri Scientific Press, 435 pp. ZooKeys, 182:109-110. https://doi.org/10.3897/zookeys.182.3105.

Plummer, P. S. and E. R. Belle. 1995. Mesozoic tectono-stratigraphic evolution of the Seychelles microcontinent. Sedimentary Geology, 96:73-91. https://doi.org/10.1016/0037-0738(94)00127-G.

Samways, M. J., P. M. Hitchins, O. Bourquin and J. Henwood. 2010. Tropical island recovery: Cousine Island, Seychelles. Wiley-Blackwell, Oxford.

Scott, H. 1910. Eight months entomological collecting in the Seychelles Islands, 1908-1909. Transactions of the Linnean Society of London (Zoology), 14:21-39. https://doi.org/10.1111/j.1096-3642.1910.tb00521.x.

Yoder, M. J, I. Mikó, K. C. Seltmann, M. A. Bertone and A. R. Deans. 2010. A Gross Anatomy Ontology for Hymenoptera. PLoS ONE, 5:e15991. https://doi.org/10.1371/journal.pone.0015991. 